\title{
In-field frequencies and characteristics of oilseed rape with double herbicide resistance
}

\author{
Antje DietZ-PfeilstetteR* and Peter ZWERGeR
}

\begin{abstract}
Institute for Biosafety of Genetically Modified Plants and Institute for Plant Protection in Field Crops and Grassland, Julius Kühn-Institut, Federal Research Centre for Cultivated Plants, Messeweg 11-12, 38104 Braunschweig, Germany
\end{abstract}

\begin{abstract}
When growing different transgenic herbicide-resistant oilseed rape cultivars side by side, seeds with multiple herbicide resistance can arise, possibly causing problems for the management of volunteer plants. Large-scale field experiments were performed in the years 1999/2000 and 2000/2001 in order to investigate the frequencies and the consequences of the transfer of herbicide resistance genes from transgenic oilseed rape to cultivars grown on neighboring agricultural fields. Transgenic oilseed rape with resistance to glufosinate-ammonium (LibertyLink, LL) and with glyphosate resistance (RoundupReady, RR), respectively, was sown in adjacent 0.5 ha plots, surrounded by about 8 ha non-transgenic oilseed rape. The plots and the field were either in direct contact ( $0.5 \mathrm{~m}$ gap width) or they were separated by $10 \mathrm{~m}$ of fallow land. Seed samples taken during harvest in the transgenic plots at different distances were investigated for progeny with resistance to the respective other herbicide. It was found that outcrossing frequencies were reduced to different extents by a $10 \mathrm{~m}$ isolation distance. In addition to pollen-mediated transgene flow as a result of outcrossing, we found considerable seed-mediated gene flow by adventitious dispersal of transgenic seeds through the harvesting machine. Volunteer plants with double herbicide resistance emerging in the transgenic plots after harvest were selected by suitable applications of the complementary herbicides Basta ${ }^{\circledR}$ and Roundup Ultra ${ }^{\circledR}$. In both years, double-resistant volunteers were largely restricted to the inner edges of the plots. Expression analysis under controlled laboratory conditions of double-resistant plants generated by manual crosses revealed stability of transgene expression even at elevated temperatures. Greenhouse tests with double-resistant oilseed rape plants gave no indication that the sensitivity to a range of different herbicides is changed as compared to non-transgenic oilseed rape.
\end{abstract}

Keywords: herbicide resistance / Brassica napus / gene flow / gene expression / gene stacking / volunteer control

\section{INTRODUCTION}

Pollen-mediated gene flow (PMGF) and the subsequent establishment of reproductive individuals are important aspects for co-existence issues associated with the cultivation of genetically modified (GM) plants. Oilseed rape (Brassica napus L.) is considered to be one of the most worrisome crops in relation to gene flow, due to its potential of outcrossing, volunteer emergence and formation of temporary feral populations. In oilseed rape, the dispersal of genes via pollen can cause the adventitious presence of transgenes in neighboring crops, feral and volunteer populations. Moreover, transgenic volunteer and feral plants may serve as additional sources for PMGF (Beckie et al., 2003; Hall et al., 2000; Knispel et al., 2008). GM oilseed rape cultivars with different types of herbicide resistance are currently cultivated on more than $4 \mathrm{M}$ ha worldwide.

*Corresponding author: antje.dietz@jki.bund.de
Under field conditions cross-pollination rates of about 25-30\% have been reported for oilseed rape (Becker et al., 1992; Rakow and Woods, 1987). Therefore two or even more herbicide resistance (HR) genes can be accidentally combined in individual offspring seeds if oilseed rape cultivars with different HR types are grown on neighboring fields. These seeds may give rise to volunteers in subsequent years, as oilseed rape seeds can remain viable in the soil for many years (Gruber et al., 2004; Jørgensen et al., 2007; Schlink, 1998). Multiple HR oilseed rape volunteers as a result of pollen flow between fields have been reported (Downey, 1999). If multiple resistant volunteer plants are not removed, e.g. by use of an appropriate herbicide, they can serve as source or sink for further cross-pollination (Beckie et al., 2003; Hall et al., 2000). Problems with volunteers harboring unknown herbicide resistances may occur, especially if one of the respective complementary herbicides 
Table 1. Seed dispersal from LL plot to RR plot during harvest compared to outcrossing rates at successive sampling points (1-10) within the RR plot.

\begin{tabular}{lccccc}
\hline $\begin{array}{l}\text { Sampling point } \\
\begin{array}{l}\text { Location } \\
\text { within plot }\end{array}\end{array}$ & No. & $\begin{array}{c}\text { Seed dispersal } \\
\text { (\% LL seeds) }\end{array}$ & $\begin{array}{c}\text { Outcrossing rate } \\
\text { (\% LL + RR seeds) }\end{array}$ & $\begin{array}{c}\text { Seed dispersal } \\
\text { (\% LL seeds) }\end{array}$ & $\begin{array}{c}\text { Outcrossing rate } \\
\text { (\% LL + RR seeds) }\end{array}$ \\
\hline at $70 \mathrm{~m}$ & 1 & 16.0 & no data & 3.2 & 0.2 \\
& 2 & 2.8 & 0 & 0.22 & 0.1 \\
& 3 & 0.44 & 0.02 & 0.14 & 0.02 \\
& 4 & 0.44 & 0 & 0.12 & 0 \\
\hline at $40 \mathrm{~m}$ & 5 & 0.16 & 0 & 0.6 & 0.2 \\
& 7 & 0.14 & 0.04 & 0.08 & 0.08 \\
& 8 & 0.16 & 0.04 & 0.04 & 0.04 \\
& 9 & 0.1 & 0.06 & 0.06 & 0.02 \\
& 10 & 0.14 & 0.04 & 0.02 & 0.06 \\
\hline
\end{tabular}

is used later on in the rotation, e.g. in a fallow field (seta-side land) or in another HR crop.

Crops with different herbicide resistances can also be the result of breeding, as is the case for several transgenic maize lines, e.g. Bt11 $\times$ GA21 and TC1507 × NK603 (AGBIOS crop database, http://www.agbios.com). In any case, the combination ('stacking') of different HR genes in one plant raises certain biosafety and co-existence issues. Gene silencing can occur due to DNA sequence homologies, as well as during development and in response to environmental conditions (Caligari et al., 1993; Dietz-Pfeilstetter et al., 2005; Matzke et al., 1993; Meyer and Saedler, 1996; Meyer et al., 1992; Park et al., 1996). Resistance to the complementary herbicides as well as the reliability of expression-based transgene detection would be affected in the case of gene silencing events. Moreover, although not very likely, pleiotropic effects of transgene integrations could potentially result in changes of sensitivity to other herbicides, which in turn may have consequences for the control of transgenic oilseed rape volunteers in the crop rotation.

The design of our field experiment made it possible to determine mutual outcrossing rates in two different adjacent oilseed rape plots, as well as to quantify the extent of transgenic seed dispersal through harvesting machines. In order to investigate possible interactions between the HR genes cp 4 epsps and pat in oilseed rape, we developed plants containing resistance to both glyphosate and glufosinate-ammonium. These plants together with parental single-resistant plants and with isogenic nonresistant plants were tested for transgene expression during plant development at two different temperatures. The same plant types were studied in the greenhouse with regard to the effects of both complementary herbicides, of three typical oilseed rape herbicides and of three herbicides commonly used to remove oilseed rape volunteers in cereal crops.

\section{RESULTS}

\section{Outcrossing frequencies}

Figure 1 shows average outcrossing rates of LL and RR herbicide resistance genes into the neighboring transgenic plot, i.e. proportions of double-resistant seeds, observed in the harvest years 2000 and 2001 as a function of gap width and distance. As expected, there is a general tendency for lower outcrossing if the gap width is increased to $10 \mathrm{~m}$. Within plots, the frequency of doubleresistant seeds decreases sharply with distance from the pollen source.

\section{Dispersal of transgenic seeds}

To determine the contribution of seeds dispersed by harvesting machines (seed-mediated gene flow) to the presence of herbicide-resistance genes originating from the adjacent plot, we performed additional PCR assays. The first 10 sampling points in the RR plot after the harvester was cleaned from seeds of the previously harvested LL plots were chosen for additional seed analysis. Glufosinate-ammonium-resistant seedlings emerging from these seed samples were tested for the LL gene as well as for RR gene sequences. In 2000, around $16 \%$ of the seeds harvested in the first sampling point of the RR plot were found to contain the pat gene only, i.e. were dispersed from the LL plot. In the following year, when the combine was cleaned more thoroughly, this number was reduced to $3.2 \%$. Table 1 gives the percentage of dispersed seeds at different successive sampling points compared to the respective outcrossing rates. 
A.

Harvest year 2000
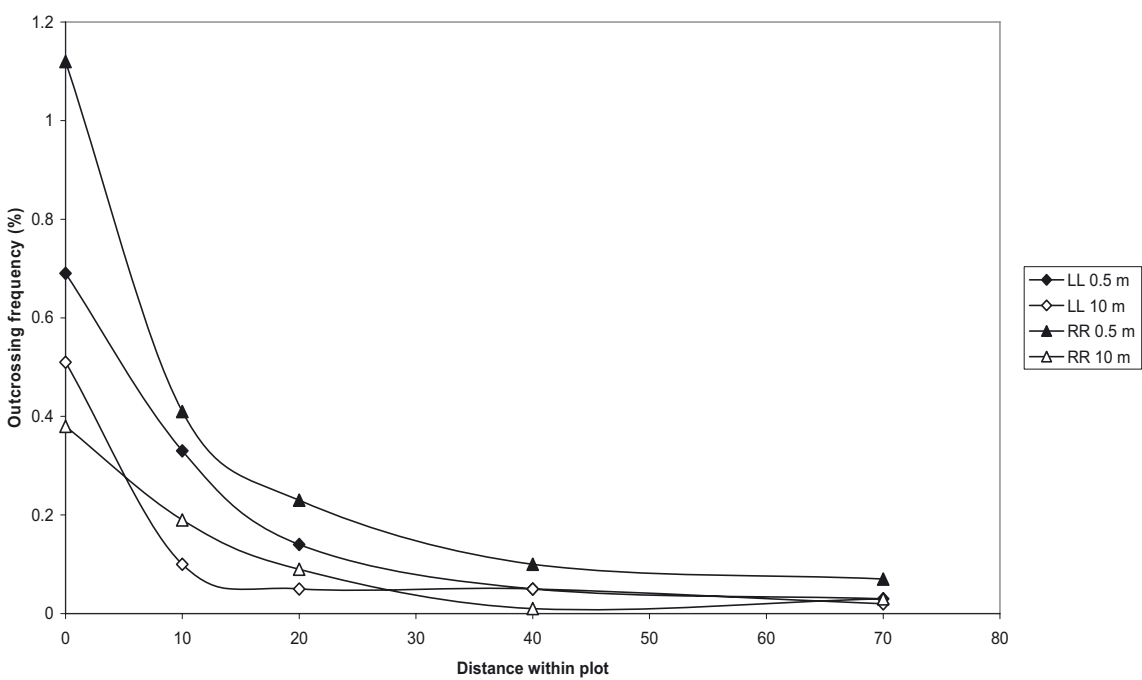

B.

Harvest year 2001

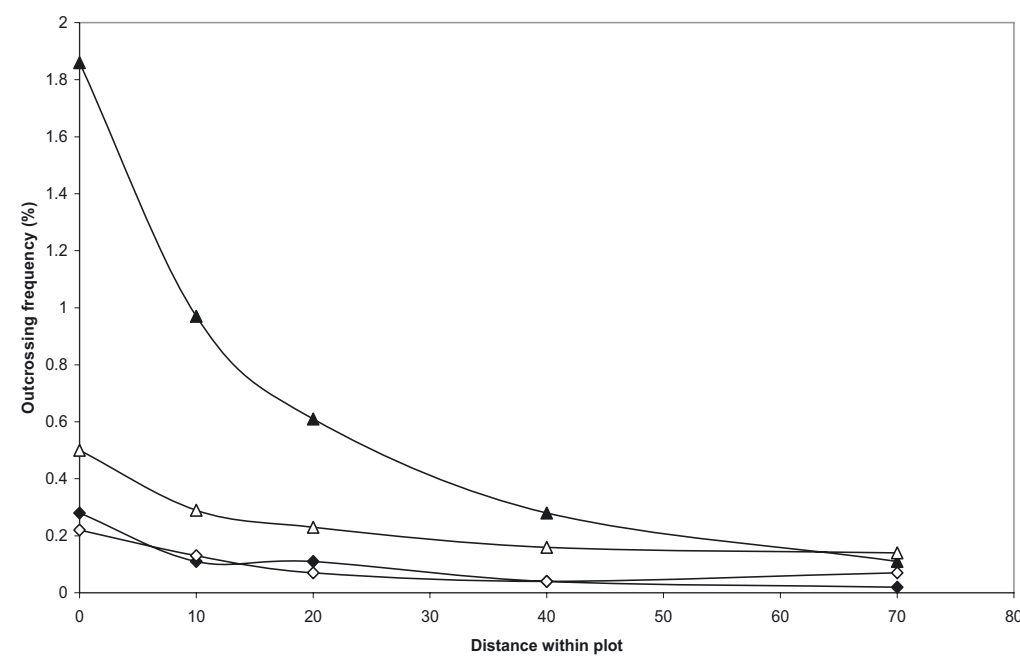

Figure 1. Average outcrossing frequencies of LL and RR genes at two different gap widths (0.5 m and $10 \mathrm{~m})$. A. Harvest year 2000 . B. Harvest year 2001 .

\section{Emergence of double-herbicide-resistant volunteers}

Volunteer plants surviving the post-harvest herbicide applications were subdivided into plants below the four-leaf stage and those above the four-leaf stage. PCR analysis of individual surviving plants showed that volunteers belonging to the small plant class often emerged only after the last herbicide application and were therefore not selected for herbicide resistance. For this reason, the quantification of double-resistant volunteers emerging after harvest was performed only on those plants above the four-leaf stage. The average number of double-resistant volunteers was between 1.5 and 6 plants per $\mathrm{m}^{2}$ at the edge of the plots facing the adjacent plot, while it was usually around 0.5 plants per $\mathrm{m}^{2}$ at distances of $40 \mathrm{~m}$ and above (Fig. 2).

\section{Expression of herbicide-resistance genes}

Expression of the pat gene and of the cp4 epsps gene was determined in double-resistant plants containing one 
A.

Harvest year 2000

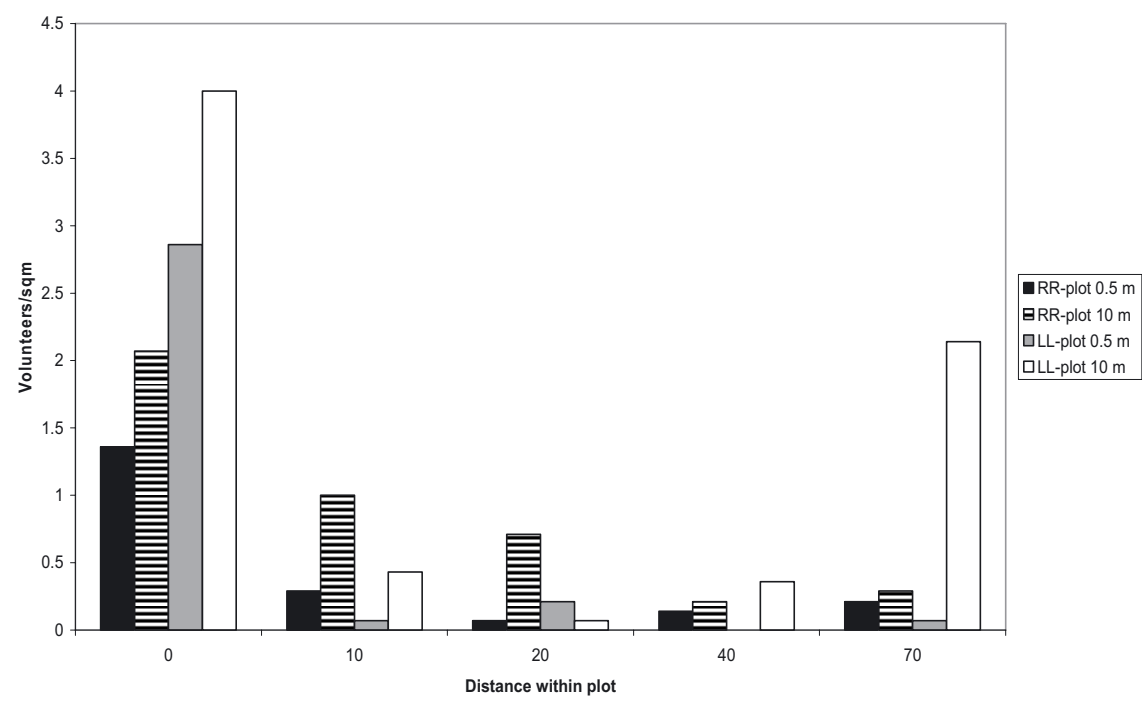

B.

Harvest year 2001

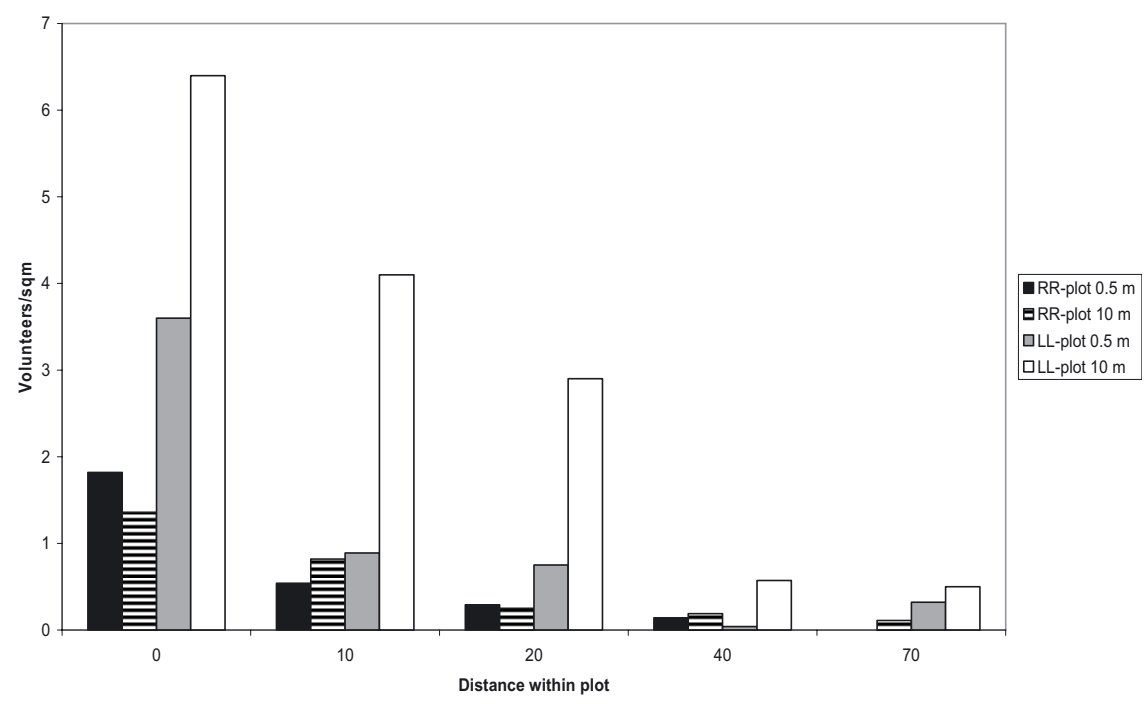

Figure 2. Double-herbicide-resistant volunteers exceeding the four-leaf stage in the LL and in the RR plots, as recorded after two post-harvest applications of the non-complementary herbicide. A. Harvest year 2000. B. Harvest year 2001.

copy of each gene, as well as in the parental homozygous LL and RR oilseed rape lines and in backcrosses of $\mathrm{LL}$ and RR with the respective non-transgenic oilseed rape cultivar. It turned out that under controlled conditions at $22{ }^{\circ} \mathrm{C}$ the expression level of both genes varied with the developmental stage; older plants at the 8- to 10 -leaf stage had about a 2 -fold increase in expression (Figs. 3 and 4). In addition, we observed a copy number dependency of gene expression (Tab. 2). Neither temperature elevation to $37^{\circ} \mathrm{C}$ nor the presence of the respective second transgene led to any gene inactivation (Tab. 2).

\section{Herbicide sensitivity of different oilseed rape lines and hybrids}

Spraying with the recommended dosage of either one of both non-selective herbicides caused death or very severe damage in plants not carrying the complementary 
Cultivation of different herbicide-resistant oilseed rape cultivars

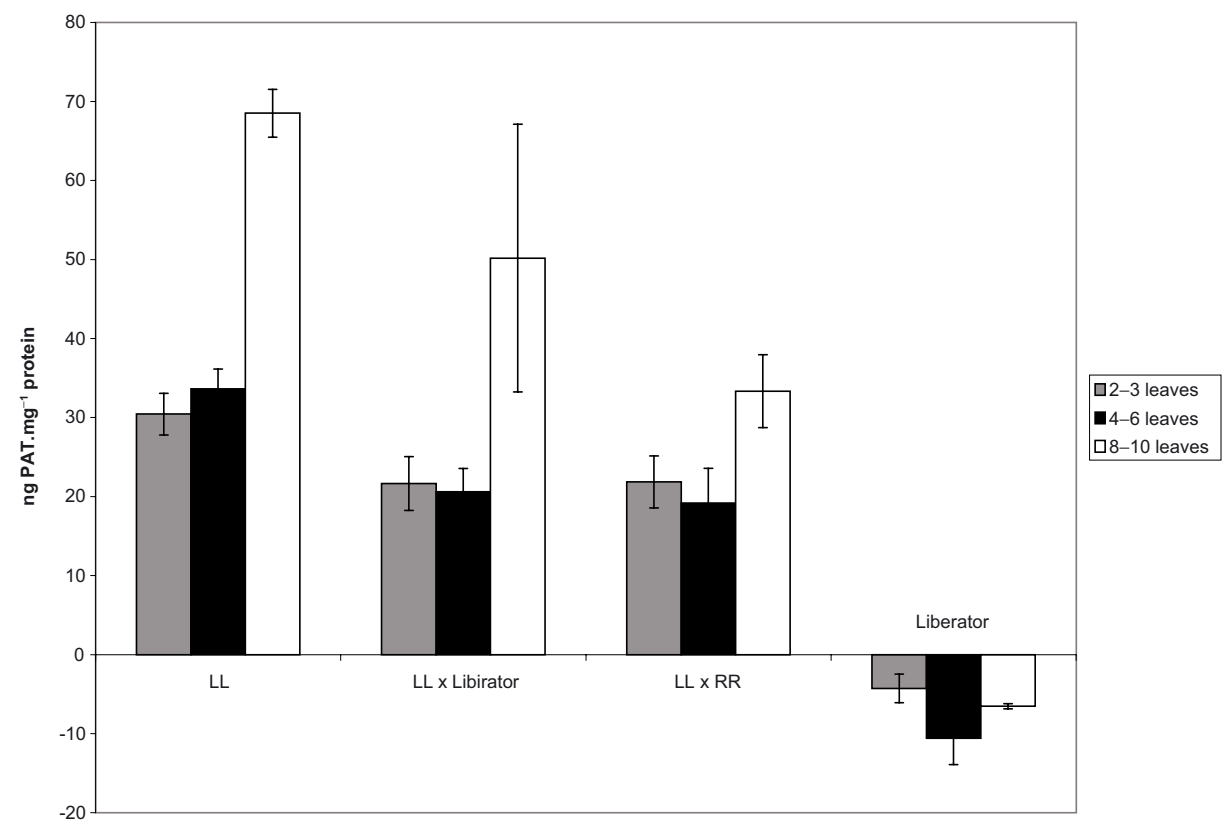

Figure 3. Expression of the pat gene during plant development, shown as relative amounts of the PAT protein.

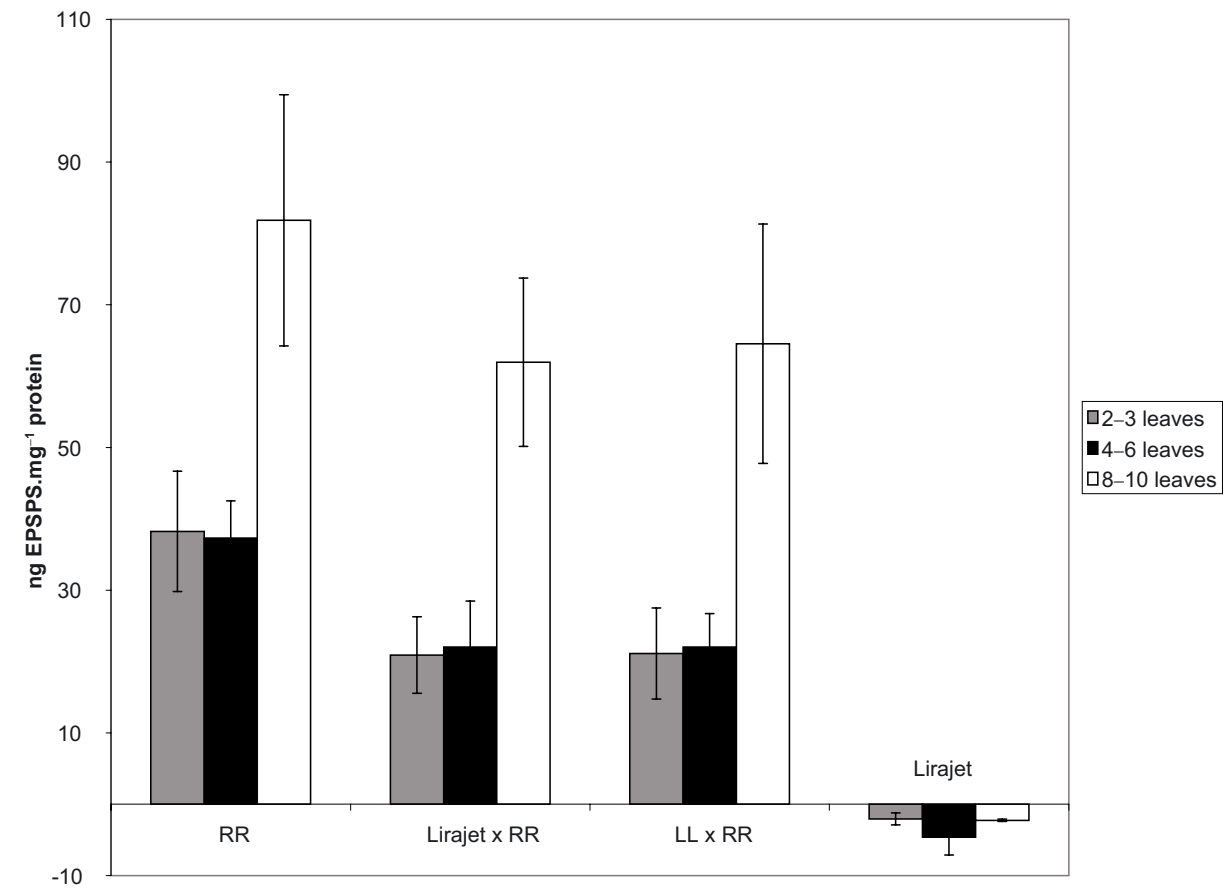

Figure 4. Expression of the cp4 epsps gene during plant development, shown as relative amounts of the CP4 EPSPS protein. 
Table 2. Correlation of protein expression (mean \pm standard deviation) at the 4 to 6-leaf stage and transgene copy number.

\begin{tabular}{|c|c|c|c|c|c|c|c|}
\hline \multirow[t]{2}{*}{ Plant line/hybrid } & \multirow[t]{2}{*}{$N$} & \multirow[t]{2}{*}{$\begin{array}{c}\text { pat } \\
\text { copies }\end{array}$} & \multicolumn{2}{|c|}{$\begin{array}{c}\text { PAT protein } \\
\text { (ng.mg }{ }^{-1} \text { total protein) }\end{array}$} & \multirow[t]{2}{*}{$\begin{array}{l}\text { cp4 epsps } \\
\text { copies }\end{array}$} & \multicolumn{2}{|c|}{$\begin{array}{c}\text { EPSPS protein } \\
\text { (ng. } \mathrm{mg}^{-1} \text { total protein) }\end{array}$} \\
\hline & & & $22{ }^{\circ} \mathrm{C}$ & $37^{\circ} \mathrm{C}$ & & $22{ }^{\circ} \mathrm{C}$ & $37^{\circ} \mathrm{C}$ \\
\hline Liberator C/6Ac (LL) & 8 & 2 & $33.6 \pm 2.5$ & $41.7 \pm 4.5$ & 0 & ND & ND \\
\hline Lirajet GT73 (RR) & 10 & 0 & ND & ND & 2 & $37.3 \pm 5.2$ & $29.4 \pm 9.3$ \\
\hline LL $\times$ Liberator & 10 & 1 & $20.6 \pm 2.9$ & $38.4 \pm 3.0$ & 0 & ND & ND \\
\hline Lirajet $\times \mathrm{RR}$ & 10 & 0 & ND & ND & 1 & $22.0 \pm 6.4$ & $19.8 \pm 6.2$ \\
\hline $\mathrm{LL} \times \mathrm{RR}$ & 10 & 1 & $19.2 \pm 4.4$ & $35.6 \pm 2.7$ & 1 & $22.3 \pm 4.7$ & $17.8 \pm 6.1$ \\
\hline
\end{tabular}

$N=$ number of individual plants tested.

$\mathrm{ND}=$ no data.

Table 3. Effectiveness (\% control) of Butisan (500 g. $\mathrm{L}^{-1}$ metazachlor) on the growth of oilseed rape cultivars, transgenic lines and transgenic hybrids (bold type $=$ recommended field rate).

\begin{tabular}{lccccccc}
\hline $\begin{array}{l}\text { Cultivar/transgenic line } \\
\text { or hybrid }\end{array}$ & \multicolumn{7}{c}{ Dosage $\left(\mathrm{L} . h a^{-1}\right)$} \\
& 0 & 0.375 & 0.75 & $\mathbf{1 . 5}$ & 2.25 & 3.0 & (Tukey) \\
\hline Liberator & 0 & 0 & 0 & 5 & 8 & 10 & 2.7 \\
Lirajet & 0 & 0 & 0 & 3 & 9 & 10 & 5.1 \\
Liberator C/6Ac (LL) & 0 & 0 & 0 & 6 & 5 & 8 & 3.4 \\
Lirajet GT73 (RR) & 0 & 0 & 0 & 5 & 6 & 11 & 3.4 \\
LL $\times$ RR & 0 & 0 & 0 & 4 & 5 & 8 & 3.8 \\
RR $\times$ LL & 0 & 0 & 0 & 5 & 5 & 5 & 0.0 \\
\hline
\end{tabular}

$\mathrm{MSD}_{0.05}=$ minimum significant difference $($ Tukey test with alpha $=0.05)$.

Table 4. Effectiveness (\% control) of Arelon flüssig (500 g.L $\mathrm{L}^{-1}$ isoproturon) on the growth of oilseed rape cultivars, transgenic lines and transgenic hybrids (bold type $=$ recommended field rate).

\begin{tabular}{lccccccc}
\hline $\begin{array}{l}\text { Cultivar/transgenic line } \\
\text { or hybrid }\end{array}$ & \multicolumn{7}{c}{ Dosage (L.ha $\left.{ }^{-1}\right)$} \\
& 0 & 0.186 & 0.375 & 0.75 & 1.5 & $\mathbf{3 . 0}$ & (Tukey) \\
\hline Liberator & 0 & 1 & 33 & 41 & 88 & 99 & 14.7 \\
Lirajet & 0 & 0 & 11 & 73 & 93 & 99 & 9.5 \\
Liberator C/6Ac (LL) & 0 & 0 & 8 & 30 & 68 & 99 & 20.5 \\
Lirajet GT73 (RR) & 0 & 4 & 34 & 83 & 93 & 99 & 11.6 \\
LL $\times$ RR & 0 & 0 & 23 & 73 & 86 & 99 & 11.3 \\
RR $\times$ LL & 0 & 11 & 39 & 96 & 99 & 99 & 9.8 \\
\hline
\end{tabular}

$\mathrm{MSD}_{0.05}=$ minimum significant difference $($ Tukey test with alpha $=0.05)$.

resistance gene. Single- or double-resistant plants, however, were only slightly affected even at twice the recommended herbicide dosage (data not shown). Presence of an additional and different HR gene did not affect the efficiency of glyphosate and glufosinate-ammonium herbicides in herbicide-resistant plants.

The three different oilseed rape herbicides all behaved very similarly, as did the three cereal crop herbicides. Therefore only results of one representative of each class are presented. With Butisan (500 g.L. ${ }^{-1}$ Metazachlor), which was chosen as a typical oilseed rape herbicide, only very slight plant damage of about $10 \%$ occurred, even at increased dosage; most notably no differences in sensitivity were observed between the tested oilseed rape cultivars and the transgenic lines and crosses (Tab. 3). Arelon flüssig (500 g.L ${ }^{-1}$ Isoproturon) served as representative of cereal herbicides, and had very good efficiency against all tested oilseed rape cultivars, lines and crosses at the recommended dosage of $3 \mathrm{~L}^{\mathrm{h}} \mathrm{ha}^{-1}$ (Tab. 4). At reduced dosages, differences in efficiencies were observed. However, these were not correlated with the transgenic HR traits. 


\section{DISCUSSION}

\section{Adventitious presence of transgenes in harvested seeds}

One major aim of our experimental approach was to determine the effect of an isolation distance of $10 \mathrm{~m}$ on outcrossing frequencies as compared to direct contact between donor and recipient plots. Generally, the frequency of PMGF is affected by plant cultivar, experimental design, local topography and environmental conditions (reviewed by Hüsken and Dietz-Pfeilstetter, 2007). Therefore in our study outcrossing frequencies varied from year to year, due to different flowering periods and weather conditions. Large differences between years and between transgenic recipient lines were observed especially in the case of direct contact between plots. While the outcrossing rates from the LL plot were about twice as high in 2000 compared to 2001, the opposite was true for PMGF from the RR plot. There were consistently pronounced differences in reciprocal outcrossing rates between the two transgenic lines. These differences are most striking for the direct-contact plots (gap width $0.5 \mathrm{~m}$ ) in 2001. The relevance of the recipient rapeseed cultivar for cross-fertilization rates has been emphasized by Rieger et al. (2002) and Simpson et al. (1999). A significant donor/recipient effect on the mutual crossfertilization rates between glyphosate-resistant and glufosinate ammonium-resistant oilseed rape cultivars was also reported by Reboud (2003) and might be due to differences in flowering time, pollen production and/or selfing rate. In contrast, in the study of Beckie et al. (2003), outcrossing rates between adjacent commercial fields of herbicide-resistant oilseed rape were generally similar for glyphosate- and glufosinate-resistant genotypes with mean values of $1.4 \%$ and $1.1 \%$, respectively, at the common border.

Alternatively, the wind direction could have affected outcrossing rates. However, the neighboring transgenic plots were not oriented in the main wind direction. Moreover, the analysis of outcrossing data into the surrounding non-transgenic field did not reveal a correlation between wind direction and outcrossing frequency, which was in accordance with results of Staniland et al. (2001).

An increased isolation distance of $10 \mathrm{~m}$ between plots resulted in reduced outcrossing frequencies. The effect of the gap width was most prominent in both years for outcrossing of the RR herbicide resistance to plants located at the edge of the LL plot. Generally, the first rows of a recipient field show a high proportion of foreign cross-pollination due to the low amount of recipient pollen produced at the field margin (Ingram, 2000; Reboud, 2003). While plants at the edge of a plot on one side act as a pollen trap, they also produce additional pollen which dilutes the incoming pollen load from the adjacent plot, thereby leading to drastically reduced outcrossing rates within the plot.

Outcrossing from neighboring plots is not the only path for gene flow between plots. As our results showed, transgenes can also be dispersed via seeds left in the harvesting machine, even if the harvester was cleaned carefully when the plots were changed. These leftover seeds can have a much greater impact on the adventitious presence of transgenic seeds in the harvest than pollen-mediated gene transfer. Therefore it is of great importance not to use the same machinery for sowing and harvest of transgenic and non-transgenic oilseed rape cultivars.

\section{Double-herbicide-resistant volunteers}

Consequences of outcrossing events from GM herbicideresistant oilseed rape are not only the adventitious presence of transgenic seeds in the harvest, but may also be the emergence of volunteer oilseed rape with new herbicide resistance traits. Oilseed rape pods are prone to shatter prior to and during harvest; which in turn results in considerable seed numbers left in the field after harvest (Price et al., 1996). As oilseed rape seeds have no primary dormancy, dehisced seeds can germinate immediately, unless secondary dormancy is induced by environmental stress conditions like water shortage or darkness (Pekrun et al., 1997). One goal of the presented field experiment was to compare the number of double-resistant seedlings emerging on the stubble as an outcome of PMGF between the two HR plots with the outcrossing frequencies obtained by seed analysis. Seeds fallen from the plants had 3.5 weeks to germinate before herbicide was applied in order to select for doubleresistant seedlings. At about the same time post-harvest, Lutman et al. (2005) found that under sufficient rainfall most of the lost seeds had germinated, i.e. on average around 3500 seeds. $\mathrm{m}^{-2}$. Taking these numbers into account, and based on the observed outcrossing rates, in the harvest year 2000 we would have expected between 13 and 40 double-resistant volunteers per $\mathrm{m}^{2}$ at the inner edge of the plots, and between 1 and 2.5 plants per $\mathrm{m}^{2}$ at $70 \mathrm{~m}$ distance within the plots. However, the numbers of double-resistant volunteers were much lower. Several reasons may account for this discrepancy: 1. lack of rainfall during the relevant time period; 2 . cracks in the soil of the experimental field site, resulting in a large number of seeds deposited to deeper soil layers thereby inducing secondary dormancy; 3 . seed predation or fatal germination. Unlike the situation in the experiment of Lutman et al. (2005), where only a small number of ungerminated seeds were left at day 22 after harvest, in our case a majority of the seeds obviously germinated only after the second application of the complementary herbicide, 
i.e. 5.5 weeks post-harvest. This was concluded based on findings that a lot of the volunteers which escaped from herbicide treatment were below the four-leaf stage. Part of these late germinating seeds had not received the respective herbicide resistance gene from the adjacent HR plot, and therefore survival of seedlings could only be explained by seed germination after the second herbicide application.

It has been repeatedly reported that on-site variability of abiotic (e.g. edaphic) and biotic factors are likely to account for the heterogeneity in the distribution of arable weeds within a field (Cardina et al., 1997; Cousens and Croft, 2000; Rew and Cousens, 2001). Likewise, these factors might have affected the emergence and/or survival of oilseed rape volunteers, and thereby also the numbers of double-resistant volunteers per $\mathrm{m}^{2}$ in the different plots. The large number of volunteers observed in 2000 at $70 \mathrm{~m}$ in one of the plots was probably caused by errors in herbicide application. That data based on herbicide sprays could result in misses and/or false positives was also conceded by Beckie et al. (2003), who investigated gene flow between commercial fields of glyphosate-resistant and glufosinateammonium-resistant oilseed rape. These authors found a large variability in gene flow among three different field sites, based on the occurrence of double herbicideresistant volunteers in the following season. Also, similar to our results, outcrossing frequencies as determined by seed analysis and gene flow data determined by means of double-herbicide-resistant volunteers were not in close agreement.

\section{Variation in gene expression}

The herbicide resistance genes pat and cp4 epsps in the transgenic oilseed rape lines are regulated by the Cauliflower mosaic virus (CaMV) $35 \mathrm{~S}$ promoter and by the Figwort mosaic virus (FMV) promoter, respectively. Both promoters have been shown to possess several short stretches of DNA sequence identity (Maiti et al., 1997; Richins et al., 1987). As homology-dependent gene silencing of transgenes under control of the CaMV 35S promoter had previously been reported (e.g. Assaad et al., 1993; Thierry and Vaucheret, 1996), it was conceivable to find reduced expression of one or both HR genes in double-resistant plants. However, although the expression level of pat and cp4 epsps genes in single-resistant as well as in double-resistant plants varied with the developmental state of the plants and with temperature, the presence of an additional transgene in the LL $\times$ RR hybrids never resulted in transgene inactivation. Instead, a gene dosage effect was observed in accordance with a number of previous reports (Beaujean et al., 1998; James et al., 2002; Tang et al., 2003). While $33.6 \mathrm{ng}$ PAT per mg total leaf protein was produced on average in the homozygous parental LL line at $22{ }^{\circ} \mathrm{C}$ at the $4-6$ leaves stage, descendants heterozygous for the pat gene contained only around $20 \mathrm{ng} \cdot \mathrm{mg}^{-1}$ PAT. These numbers as well as the EPSPS protein amounts in homozygous versus heterozygous plants correspond to the gus gene expression data of Beaujean et al. (1998) who demonstrated a 50\% increase in the expression level in homozygous plants as compared to heterozygous tobacco transformants.

\section{Herbicide sensitivity}

Two main aspects concerning the herbicide sensitivity of double- or single-transgenic HR oilseed rape plants were addressed. The first concerned the compatibility of the plants with herbicides commonly used in oilseed rape fields. No differences between transgenic plants and the isogenic lines were observed. The slight plant damage seen in all tested cultivars or lines if the rate of Butisan was doubled, was probably due to the fact that greenhouse-grown plants generally show greater herbicide susceptibility than plants grown in the field. Similar observations were made by Senior et al. (2002), who found that the herbicide Benazolin applied to glass house plants severely damaged all lines of winter and spring oilseed rape, although this herbicide is used in the field for selective weed control in Brassica crops. Also in accordance with Senior et al. (2002), we found that resistance to the complementary herbicides was not affected by the second transgene. In conclusion, to control weeds in transgenic HR oilseed rape stands, not only the complementary non-selective herbicides can be used, but also the conventional selective herbicides.

The second question concerned the control of doubleresistant plants with herbicides commonly used to control oilseed rape volunteers in the crop rotation. It was found that transgene integration as well as the combination of the different HR genes did not lead to pleiotropic effects affecting sensitivity to cereal herbicides used for controlling broad-leaved weed species. This is in agreement with the results of Beckie et al. (2004), who also reported that oilseed rape with multiple herbicide-resistance traits does not differ from non-transgenic cultivars with respect to sensitivity to herbicides commonly used for volunteer control. Therefore, with such herbicides volunteer oilseed rape plants can be controlled efficiently in succeeding cereal stands.

\section{MATERIALS AND METHODS}

\section{Plant material}

Seeds of the GM RoundupReady (RR) oilseed rape line Lirajet GT73 were supplied by Monsanto Deutschland, 
while seeds of the transgenic LibertyLink (LL) oilseed rape line Liberator $\mathrm{C} / 6 \mathrm{Ac}$ were obtained from Hoechst Schering AgrEvo (now: Bayer CropScience). The rapeseed line Lirajet GT73 contains a single copy insert with one cp4 epsps gene (AGBIOS crop database, http://www.agbios.com). Liberator C/6Ac resulted from selfing of rapeseed transformant Liberator 8/92-01 and was shown to contain a single copy of the pat gene (information of Hoechst Schering AgrEvo). The parental winter oilseed rape cultivars Lirajet and Liberty served as non-transgenic controls in gene expression and herbicide sensitivity experiments. Double-resistant plants and heterozygous backcross plants were generated by reciprocal crosses in the greenhouse.

\section{Experimental field design}

Field experiments with transgenic winter oilseed rape were performed in two consecutive years (1999/2000 and 2000/2001) in different fields. Each field experiment consisted of two double plots of 1 ha size, half with LL and half with RR oilseed rape. While in one of the double plots the transgenic lines were separated by $0.5 \mathrm{~m}$, the second double plot had $10 \mathrm{~m}$ separation distance. The double plots were each surrounded by a $50 \mathrm{~m}$ wide nontransgenic border consisting of a mixture of Lirajet and Liberator plants. Sowing took place in August of the years 1999 and 2000. After completion of flowering all plants were cut and incorporated into the soil except for $2 \mathrm{~m}$ wide sampling strips located at different distances $(0$, $10,20,40,70 \mathrm{~m}$ ) from the inner edge of each plot.

\section{Sampling and phenotypic analysis of seeds}

Harvesting of the $2 \mathrm{~m}$ wide sampling strips took place in July of the years 2000 and 2001. Between the different HR plots, harvesting machines were cleaned. Seed samples were taken from seven $5 \mathrm{~m}$ long sections in each strip, thereby obtaining seed samples from 35 sampling sites per HR plot. Parts of the seed samples ( 5 per sampling strip) were analyzed for resistance to glyphosate and/or to glufosinate-ammonium by phenotypic herbicide germination tests. To this end between 500 and 10000 seeds per sample were germinated in trays on filter paper soaked with aqueous solutions of either $0.005 \%$ Basta $^{\circledR}$ (Pfeilstetter et al., 2000) or $0.005 \%$ Roundup ${ }^{\circledR}$. In order to detect seeds with double herbicide resistance, seeds from the LL plot were subject to Roundup ${ }^{\circledR}$ treatment and seeds from the RR plot were treated with the glufosinate-ammonium herbicide Basta ${ }^{\circledR}$. After $7-10$ days at $20^{\circ} \mathrm{C}$ seedlings were classified as resistant or sensitive. Seedlings classified as resistant or probably resistant were potted in soil for subsequent PCR analysis.

\section{Polymerase chain reaction (PCR)}

DNA was isolated from leaf material according to the CTAB method described by Tinker et al. (1993). For PCR amplifications $100 \mathrm{ng}$ DNA was used as a template. Primers and reaction conditions for the LL-specific PCR were as described by Pfeilstetter et al. (2000). RR-specific PCR was conducted with the primers RT73-1/RT73-2 according to the Standard Operating Procedure provided by Monsanto Company (confidential). Control reactions using primers complementary to universal regions of plant chloroplast tRNA (Taberlet et al., 1991) were performed to test the amplification efficiency of DNA (i.e. to test for PCR inhibitors). Fifteen $\mu \mathrm{L}$ of PCR products were loaded on a $1 \%$ agarose gel for electrophoresis.

\section{Screening for double-resistant volunteers in the field}

For selection of double-herbicide-resistant volunteers emerging on the HR plots after harvest, LL plots were sprayed with Roundup Ultra ${ }^{\circledR}$ (active ingredient: 360 g. $\mathrm{L}^{-1}$ glyphosate) and RR plots were sprayed with Basta $^{\circledR}$ (active ingredient: 200 g.L $\mathrm{L}^{-1}$ glufosinate ammonium). Starting 3.5 weeks post-harvest, the herbicides were applied twice at a rate of $3 \mathrm{~L}^{-\mathrm{ha}^{-1}}$ with an interval of 14 days. Surviving plants were classified according to size. Leaf samples of individual plants were taken for PCR analysis.

\section{Analysis of gene expression by enzyme linked immunosorbent assay (ELISA)}

Expression of the herbicide resistance genes pat and cp4 epsps was determined at two temperatures and at three different developmental stages. Roughly ten plants per genotype were grown either at $22{ }^{\circ} \mathrm{C}$ or at $37^{\circ} \mathrm{C}$ in the greenhouse. At each time point (2- to 3-, 4- to 6-, 8to 10-leaf stage) about half of the third leaf from the top of the plants was removed to prepare protein extracts according to the instructions of the ELISA procedures. The total protein of the extracts was determined using a protein assay kit (Bio-Rad).

For PAT (phosphinothricin acetyltransferase) protein quantification, an ELISA test kit was obtained from Steffens Biotechnische Analysen GmbH (Ebringen, Germany). Protein extracts were usually applied to microtiter plate wells at a concentration of $200 \mu \mathrm{g} \cdot \mathrm{mL}^{-1}$. The absorption was measured at $655 \mathrm{~nm}$ and converted into ng PAT. $\mathrm{mg}^{-1}$ total protein using PAT standards.

CP4 EPSPS (5-enol pyruvyl shikimate 3-phosphate synthase) was quantified with CP4-specific antibodies 
and CP4 EPSPS protein standards according to the Standard Operating Procedure provided by Monsanto Company (confidential). Extracts were diluted to $100 \mu \mathrm{g} \cdot \mathrm{mL}^{-1}$ before loading on a microtiter plate. The absorption was measured at $405 \mathrm{~nm}$ and converted into $\mathrm{ng} \mathrm{CP} 4$ EPSPS. $\mathrm{mg}^{-1}$ total protein.

\section{Herbicide applications in the greenhouse}

For testing the herbicide sensitivity of the double- and single-transgenic HR oilseed rape plants and of the isogenic lines, a bioassay was carried out under greenhouse conditions. Six different herbicides were used, three selective herbicides for controlling weeds in oilseed rape (Butisan (500 g.L $\mathrm{L}^{-1}$ metazachlor), Lentagran WP (450 g. $\mathrm{kg}^{-1}$ pyridate), Lontrel 100 (100 g.L ${ }^{-1}$ clopyralide)), and three selective herbicides controlling broadleaved weeds and volunteer oilseed rape plants in cereals (Arelon flüssig (500 g. $\mathrm{L}^{-1}$ isoproturon), Pointer (750 g.kg ${ }^{-1}$ tribenuron), Starane 180 (180 g.. ${ }^{-1}$ fluoxypyr)). All herbicides were tested in five rates and an untreated control, with a range up to the double of the recommended field rate for the oilseed rape herbicides, and up to the field rate for the cereal herbicides. The herbicide Pointer was tested only up to the half of the field rate due to the high herbicidal activity against cruciferous plants. The application was done at the 2- to 3-leaf stage of the plants with a lab sprayer. Each herbicide treatment was done in four replicates with five plants per genotype and treatment. Before and after application, plants were cultivated in a greenhouse with temperatures from 15 to $20{ }^{\circ} \mathrm{C}$. Two weeks after the treatment, efficacy (\% control) was determined based on the plant biomass (above ground). The trial was designed as a randomized block.

\section{ACKNOWLEDGEMENTS}

We thank the seed company DSV for providing the oilseed rape seeds and the companies Monsanto and AgrEvo (now: Bayer CropScience) for technical support. For their excellent technical assistance we thank Sandra Heilmann and Arno Littmann. The work was supported by the German Ministry of Education and Research (BMBF).

Received November 6, 2008; accepted May 13, 2009.

\section{REFERENCES}

Assaad FF, Tucker KL, Signer ER (1993) Epigenetic repeatinduced gene silencing (RIGS) in Arabidopsis. Plant Mol. Biol. 22: 1067-1085
Beaujean A, Sangwan RS, Hodges M, Sangwan-Norreel BS (1998) Effect of ploidy and homozygosity on transgene expression in primary tobacco transformants and their androgenetic progenies. Mol. Gen. Genet. 260: 361-371

Becker HC, Damgaard C, Karlsson B (1992) Environmental variation for outcrossing rate in rapeseed (Brassica napus). Theor. Appl. Genet. 84: 303-306

Beckie HJ, Warwick SI, Nair H, Séguin-Swartz G (2003) Gene flow in commercial fields of herbicide-resistant canola (Brassica napus). Ecol. Appl. 13: 1276-1294

Beckie HJ, Séguin-Swartz G, Nair H, Warwick SI, Johnson E (2004) Multiple herbicide-resistant canola can be controlled by alternative herbicides. Weed Sci. 52: 152-157

Caligari PDS, Yapabandara YMHB, Paul EM, Perret J, Roger P, Dunwell JM (1993) Field performance of derived generations of transgenic tobacco. Theor. Appl. Genet. 86: 875-879

Cardina J, Johnson GA, Sparrow DH (1997) The nature and consequences of weed spatial distribution. Weed Sci. 45: 364373

Cousens R, Croft AM (2000) Weed populations and pathogens. Weed Res. 40: 63-82

Dietz-Pfeilstetter A, Barg E, Weber A (2005) Gene expression in transgenic virus resistant and herbicide-resistant plants under greenhouse and under field conditions. Nachrichtenbl. Deut. Pflanzenschutzd. 57: 167-171

Downey RK (1999) Gene flow and rape - the Canadian experience. In Lutman PJW, ed, Gene Flow and Agriculture - Relevance for Transgenic Crops, British Crop Protection Council, Vol. 72, pp 109-116

Gruber S, Pekrun C, Claupein W (2004) Population dynamics of volunteer oilseed rape (Brassica napus L.) affected by tillage. Eur. J. Agron. 20: 351-361

Hall L, Topinka K, Huffman J, Davis L, Good A (2000) Pollen flow between herbicide-resistant Brassica napus is the cause of multiple-resistant B. napus volunteers. Weed Sci. 48: 688-694

Hüsken A, Dietz-Pfeilstetter A (2007) Pollen-mediated intraspecific gene flow from herbicide resistant oilseed rape (Brassica napus L.). Transgenic Res. 16: 557-569

Ingram J (2000) The separation distances required to ensure cross-pollination is below specified limits in non-seed crops of sugar beet, maize and oilseed rape. Plant Var. Seeds 13: 181-199

James VA, Avart C, Worland B, Snape JW, Vain P (2002) The relationship between homozygous and hemizygous transgene expression levels over generations in populations of transgenic rice plants. Theor. Appl. Genet. 104: 553-561

Jørgensen T, Hauser TP, Jørgensen RB (2007) Adventitious presence of other cultivars in oilseed rape (Brassica napus) from seed banks and certified seed. Seed Science Res. 17: $115-125$

Knispel AL, McLachlan SM, Van Acker RC, Friesen LF (2008) Gene flow and multiple herbicide resistance in escaped canola populations. Weed Sci. 56: 72-80 
Lutman PJW, Berry K, Payne RW, Simpson E, Sweet JB, Champion GT, May MJ, Wightman P, Walker K, Lainsbury M (2005) Persistence of seeds from crops of conventional and herbicide tolerant oilseed rape (Brassica napus). Proc. Royal Soc. B-Biol. Sci. 272: 1909-1915

Maiti IB, Gowda S, Kiernan J, Ghosh SK, Shepherd RJ (1997) Promoter/leader deletion analysis and plant expression vectors with the figwort mosaic virus (FMV) full length transcript (FLt) promoter containing single or double enhancer domains. Transgenic Res. 6: 143-156

Matzke MA, Neuhuber F, Matzke AJM (1993) A variety of epistatic interactions can occur between partially homologous transgene loci brought together by sexual crossing. Mol. Gen. Genet. 238: $379-386$

Meyer P, Saedler H (1996) Homology-dependent gene silencing in plants. Annu. Rev. Plant Physiol. Plant Mol. Biol. 47: $23-48$

Meyer P, Linn F, Heidmann I, Meyer ZAH, Niedenhof I, Saedler H (1992) Endogenous and environmental factors influence $35 \mathrm{~S}$ promoter methylation of a maize A1 gene construct in transgenic petunia and its colour phenotype. Mol. Gen. Genet. 231: 345-352

Park Y-D, Papp I, Moscone EA, Iglesias VA, Vaucheret H, Matzke AJM, Matzke MA (1996) Gene silencing mediated by promoter homology occurs at the level of transcription and results in meiotically heritable alterations in methylation and gene activity. The Plant J. 9: 183-194

Pekrun C, Lutman PJW, Baeumer K (1997) Induction of secondary dormancy in rape seeds (Brassica napus L.) by prolonged imbibition under conditions of water stress or oxygen deficiency in darkness. Eur. J. Agron. 6: 245-255

Pfeilstetter E, Matzk A, Feldmann SD, Schiemann J (2000) Rapid and efficient screening of phosphinothricin tolerant oilseed rape (Brassica napus) with a novel germination test. Euphytica 113: 119-124

Price JS, Hobson RN, Neale MA, Bruce DM (1996) Seed losses in commercial harvesting of oilseed rape. J. Agricultural Engineering Research 65: 183-191

Rakow G, Woods DL (1987) Outcrossing in rape and mustard under Saskatchewan prairie conditions. Can. J. Plant Sci. 67: $147-151$
Reboud X (2003) Effect of a gap on gene flow between otherwise adjacent transgenic Brassica napus crops. Theor. Appl. Genet. 106: 1048-1058

Rew LJ, Cousens RD (2001) Spatial distribution of weeds in arable crops: are current sampling and analytical methods appropriate? Weed Res. 41: 1-18

Richins RD, Scholthof HB, Shepherd RJ (1987) Sequence of figwort mosaic virus DNA (caulimovirus group). Nucl. Acids Res. 15: 8451-8466

Rieger MA, Lamond M, Preston C, Powles SB, Roush RT (2002) Pollen-mediated movement of herbicide resistance between commercial canola fields. Science 296: 2386-2388

Schlink S (1998) 10 years survival of rape seed (Brassica napus L.) in soil. J. Plant Diseases Protection, Special Issue XVI: 169-172

Senior IJ, Moyes C, Dale PJ (2002) Herbicide sensitivity of transgenic multiple herbicide-tolerant oilseed rape. Pest Manag. Sci. 58: 405-412

Simpson EC, Norris CE, Law JR, Thomas JE, Sweet JB (1999) Gene flow in genetically modified herbicide tolerant oilseed rape (Brassica napus) in the UK. In Lutman PJW, ed, Gene Flow and Agriculture - Relevance for Transgenic Crops, British Crop Protection Council, Vol. 72, pp 75-81

Staniland BK, McVetty PBE, Friesen LF, Yarrow S, Freyssinet G, Freyssinet M (2001) Effectiveness of border areas in confining the spread of transgenic Brassica napus pollen. Can. J. Plant Sci. 80: 521-526

Taberlet P, Gielly L, Pautou G, Bouvet J (1991) Universal primers for amplification of three noncoding regions of chloroplast DNA. Plant Mol. Biol. 17: 1105-1109

Tang J, Scarth R, Fristensky B (2003) Effects of genomic position and copy number of Acyl-ACP thioesterase transgenes on the level of the target fatty acids in Brassica napus L. Mol. Breed. 12: 71-81

Thierry D, Vaucheret H (1996) Sequence homology requirements for transcriptional silencing of $35 \mathrm{~S}$ transgenes and post-transcriptional silencing of nitrite reductase (trans)genes by the tobacco 271 locus. Plant Mol. Biol. 32: 1075-1083

Tinker NA, Fortin MG, Mather DE (1993) Random amplified polymorphic DNA and pedigree relationships in spring barley. Theor. Appl. Genet. 85: 976-984 